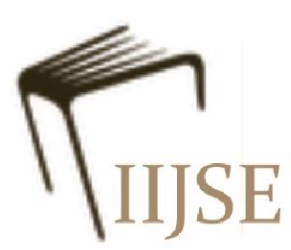

\title{
PENGEMBANGAN PRODUK KERIPIK PISANG DENGAN METODE QUALITY FUNCTION DEPLOYMENT (QFD) Studi Kasus: UD. Syahriyah
}

\author{
Januariana Nanda Eka ${ }^{1}$ \\ Universitas Trunojoyo \\ elisananda494@gmail.com
}

\begin{abstract}
Abstrak
Kata kunci:

Pengembangan

produk, Keripik

pisang, Metode

QFD

Era persaingan industri yang semakin kompetitif menuntut setiap industri untuk secara cermat melakukan berbagai upaya produktif, menuntut perusahaan agar dapat melakukan inovasi produk secara kreatif, salah satunya melakukan pengembangan produk. Hal ini bertujuan untuk mengetahui produk keripik pisang sesuai dengan harapan konsumen. Metode yang digunakan dalam penelitian ini adalah metode QFD (Quality Function Deployment) menunjukkan terdapat tujuh belas atribut kebutuhan konsumen, sebelas atribut dari segi produk dan enam atribut dari segi kemasan. Pada persyaratan teknis terdapat dua puluh satu atribut, enam belas atribut dari segi produk dan lima atribut dari segi kemasan dalam mengembangkan produk keripik pisang yang sesuai dengan harapan konsumen. Atribut yang perlu di kembangkan dari segi produk adalah atribut warna keripik kuning kecoklatan dengan nilai 1,278 dan dari segi kemasan atribut desain produk menarik dengan nilai 1,596.
\end{abstract}

\begin{abstract}
The increasingly competitive era of industrial competition demands every industry to carefully undertake various productive efforts and demand company in order to make product innovation creatively, one of the is product development. It is intended to know the product of banana chips in accordance with the consumer's expectations. The method used in this research is QFD (Quality Function Deployment) showing that there are seventeen attributes of consumers' need, eleven attributes in terms of products and six attributes in terms of packaging. On the technical terms, there are twenty-one attributes, six twelve attributes in terms of products and five attributes in terms of inner packaging in developing a banana chips product that fits the expectations of consumers. Attributes that needs to be developed in terms of products is the color attribute of yellow brown chips with a value of 1.278 and in terms of packaging attributes of an attractive product design with a value of 1.596 .
\end{abstract}

Keyword:

Product

Development,

Banana Crackers,

QFD Method 


\section{A. Pendahuluan}

Pisang merupakan salah satu komoditas pertanian yang sangat digemari masyarakat, dan menjadi salah satu komoditas tanaman buah yang mulai dikebunkan. Di Indonesia pisang masih bisa ditanam oleh masyarakat sebagai tanaman pekarangan dan perkebunan dalam skala kecil, pemeliharaan serta pemanfaatannya kurang maksimal, Untuk itu perlu ada suatu pendekatan khusus agar tanaman pisang dikenal manfaatnya secara luas oleh masyarakat (Prihatini et al. 1999). UD. Syahriyah adalah usaha yang bergerak di bidang industri makanan kecil sejak tahun 2004 dengan keripik singkong sebagai produk utamanya, terletak di J1. Mutiara 72 Sampang, Madura. Seiring berjalan waktu usaha ini mulai melakukan diversifikasi produk dengan memproduksi produk keripik pisang guna untuk meningkatkan volume penjualan. Permasalahan yang dihadapi saat ini adalah kegiatan pemasaran yang belum sepenuhnya maksimal jika dilihat dari hasil penjualan keripik pisang yang masih rendah dibanding keripik singkong.

Rendahnya penjualan keripik pisang karena banyaknya pesaing sehingga menimbulkan persaingan yang ketat dalam memperoleh konsumen. Langkah awal yang perlu dilakukan UD. Syahriyah ialah memperbaiki dan meningkatkan kualitas keripik pisang.
Pengembangan produk merupakan kegiatan untuk membuat produk yang lebih baik dari produk sebelumnya dengan harapan dapat meningkatkan minat beli konsumen (Machyudi, 2009).

Metode Quality Function Deployment (QFD) yang digunakan untuk formulasi strategi pengembangan produk dan merupakan salah satu metode yang tepat untuk merumuskan kebutuhan teknis dalam usaha meningkatkan kualitas produk. Metode QFD dipilih karena mampu menerjemahkan apa yang dibutuhkan konsumen ke dalam sebuah produk, guna memperbaiki dan mengembangkan produk sesuai dengan kebutuhan konsumen.

Menurut Wijaya (2011) QFD merupakan pendekatan sistematik yang menentukan tuntutan konsumen kemudian tuntutan itu diterjemahkan secara akurat dalam desain teknis, manufacturing, dan perencanaan produksi yang tepat. Pada prinsipnya, QFD membantu mendengarkan keinginan konsumen dan berguna untuk brainstrorming sessions bagi produsen dalam menentukan cara terbaik memenuhi keinginan konsumen serta prioritas perbaikan yang perlu diterapkan oleh UD. Syahriyah dalam mengembangkan produk keripik pisang.

\section{B. Metode Penelitian}

Penelitian ini dilakukan di Industri Keripik Pisang UD. Syahriyah yang berlokasi di Jl. 
Mutiara 72 Sampang, Madura. Penelitian ini dilakukan pada tanggal 23 September sampai Oktober 2017. Penelitian berfokus pada kualitas produk dan berdasarkan pada persepsi konsumen keripik pisang UD. Syahriyah. Metode yang digunakan adalah QFD sampai pada tahap planning matrix perusahaan kompetitor yang dipilih adalah UD. Melati. Pengolahan data penelitian dilakukan di Laboratorium Teknologi Industri Pertanian, Fakultas Pertanian, Universitas Trunojoyo Madura.

Penentuan responden menggunakan jumlah populasi yang ada, dimana teknik tersebut digunakan untuk menetapkan jumlah sampel dengan cara memilih sampel yang dikehendaki oleh peneliti (Wijaya 2011). Responden yang mengisi kuesioner adalah konsumen yang pernah mengkonsumsi keripik pisang dalam kurun waktu sebulan terakhir di UD. Syahriyah. Penentuan jumlah sampel berdasarkan rumus Cacrhan karena popilasi sudah diketahui (Wijaya 2011).

$$
\begin{gathered}
n=\frac{N P Q}{(N-1) D+P Q} \\
n=\frac{1339,83 \times(0,5) \times(1-0,5)}{(1339,83-1)\left[\frac{\left.(0,05)^{2}\right]+(0,5) \times(1-0,5)}{1,96}\right]}=172
\end{gathered}
$$

Dimana:

$\mathrm{n}$ : Jumlah minimal sampel

$\mathrm{N}$ : Jumlah rata-rata pelanggan (populasi)

P: Proporsi responden memilih pertanyaan tertentu $(0.5)$
Q: (1- $p$ ) Proporsi responden yang tidak memilih pertanyaan tertentu $(0.5)$

D: Tingkat ketelitian $\frac{B^{2}}{Z^{a / 2}}$

B: Tingkat kesalahan $0.05(\mathrm{Z} a / 2=1,96)$

\section{Analisis Data}

Tahapan pengolahan data menggunakan QFD adalah sebagai berikut :

1. Penentuan bentuk produk

2. Identifikasi kebutuhan konsumen

3. Analisis tingkat kepentingan konsumen (TKK), dengan skala Sangat penting (5), Penting (4), Ragu-ragu (3), Tidak penting (2). Sangat tidak penting (1) (Ginting 2010)

$$
T K K=\frac{\sum x}{N}
$$

TKK tingkat kepentingan konsumen, EX total skor kepentingan, $\mathrm{N}$ jumlah sampel.

4. Uji validitas dan reliabilitas - diperoleh dari kuesioner tingkat kepentingan konsumen (TKK)

5. Analisis tingkat kepuasan pelanggan (TKP)

$$
T K P=\frac{\sum x}{N}
$$

TKP tingkat kepuasan pelanggan, EX total skor kepentingan, $\mathrm{N}$ jumlah sampel

6. Analisis tingkat perbandingan produk kompetitor - didapatkan dari analisis tingkat kepuasan pelanggan (TKP)

7. Target (Goal) - perbandingan nilai tertinggi dari TKK dan TKP 
8. Improvement Ratio (IR) - menentukan tingkatan yang ingin dicapai perusahaan untuk memenuhi kebutuhan konsumen

$$
I R=\frac{\text { target }}{T K P}
$$

9. Poin penjualan - menunjukkan seberapa besar pengaruh pemenuhan kebutuhan konsumen terhadap penjualan produk

10. Raw weight-menunjukkan kepentingan akhir konsumen Raw Weight $=$ TKK $\times$ IR $\times$ Poin penjualan

11. Normalized raw weight - menunjukkan pentingnya nilai raw weight dibanding dengan nilai raw weight total

$$
N R W=\frac{\text { Rawweight }}{\text { Raw Weight Total }}
$$

12. Pembuatan respon teknis - tanggapan dari 2 pakar yang digunakan untuk merespon kenutuhan konsumen.

13. Pembuatan matrik korelasi menghubungkan antara persyaratan teknis dengan atribut kebutuhan konsumen dengan skla Tidak ada hubungan (0), Lemah (1), Sedang (3), Kuat (9).

14. Pembuatan matrik trade off menghubungkan antara persyaratan teknis dengan persyaratan teknis lainnya

15. Penentuan prioritas persyaratan teknis menentukan prioritas perbaikan pada respon teknis
16. Analisis data - semua data yang dikelola pada semua tahapan sebelumnya kemudian dimasukan dan diolah dalam matrik HOQ berdasarkan bagian atau klasifikasi atribut yang sudah ditentukan.

\section{Hasil dan Pembahasan}

1. Identifikasi Kebutuhan Konsumen

Tahap identifikasi ini bertujuan untuk mengetahui apa saja yang dibutuhkan konsumen dalam mengembangkan produk keripik pisang. Griffin dan Hauser dalam studinya memperkirakan bahwa 90\% kebutuhan pelanggan diperoleh dari proses wawancara kepada 30 responden. Hasil dari wawancara dapat dilihat pada tabel Identifikasi Kebutuhan Konsumen diatas.

2. Analisis Tingkat Kepentingan Konsumen Analisis ini bertujuan untuk menilai seberapa penting atribut kebutuhan konsumen yang akan dikembangkan berdasarkan tingkat kepentingannya. Pada tabel 1 TKK menunjukkan bahwa konsumen memilih atribut tekstur keripik renyah tidak alot $(4,69)$ merupakan atribut paling penting untuk pertimbangan membeli produk keripik pisang dari segi produk, sedangkan dari segi kemasan didapatkan nilai tertinggi atribut mencantumkan label halal, komposisi, tanggal kadaluarsa $(4,56)$. 
3. Uji Validitas dan Reliabilitas

Uji ini digunakan untuk mengetahui sejauh mana kuesioner yang digunakan bersifat valid atau reabel dalam penilaian setiap atribut sehingga dapat dipercaya. Tabel 1 menunjukkan bahwa seluruh atribut bersifat valid karena $>0,197$ dan dinyatakan reabel karena $>0,6$.

4. Analisis Tingkat Kepuasan Pelanggan Bertujuan untuk mengetahui tingkat kepuasan pelanggan terhadap produk keripik pisang. Tabel 1 TKP dari segi produk pelanggan merasa puas terhadap atribut produk higienis dan sehat untuk dikonsumsi dengan nilai kepuasan sebesar 4,30. Sedangkan dari segi kemasan tingkat kepuasan tertinggi terhadap kemasan simpel (plastik bening dengan penutup sealer dan alumunium dengan penutup katupan) dengan nilai kepuasan 3,96.

5. Analisis Tingkat Perbandingan dengan Produk Kompetitor

Berdasarkan perbandingan yang telah dilakukan dengan produk kompetitor dapat diketahui bahwa total tingkat kesukaan konsumen dari segi produk UD. Syahriyah sebesar 41,35 dan dari segi kemasan sebesar 19,08. Sedangkan dari produk kompetitor dari segi produk sebesar 41,53 dan dari segi kemasan sebesar 22,52.
6. Penentuan Target Goal dan IR

Nilai target merupakan nilai perbandingan antara TKK dan TKP. Berdasarkan pada tabel 1 nilai target didapatkan dari nilai TKK karena nilai tersebut lebih tinggi . Nilai IR yang $>1$ perlu dilakukan perbaikan, semakin besar nilai IR maka semakin besar pula usaha yang dilakukan untuk perbaikan.

7. Penentuan Point Penjualan

Penentuan poin penjualan bertujuan untuk memberikan penilaian terhadap atribut penjualan produk keripik pisang. Hasil tabel 1 dari segi produk atribut tidak ada bahan pengawet adalah atribut yang paling berperan terhadap penjualan produk keripik pisang Sedangkan segi kemasan atribut yang memiliki nilai poin penjualan tertinggi adalah atribut label halal, mencantumkan komposisi dan kadaluarsa dan mencantumkan BPOM dimana atribut tersebut memiliki nilai poin penjualan tertinggi diantara nilai poin penjualan dari semua atribut segi kemasan.

8. Raw Weight dan Normalized Raw Weight Nilai RW dan NRW dapat dilihat pada tabel 1 dapat diketahui bahwa nilai RW dan NRW tertinggi pada atribut segi produk tidak banyak minyak pada keripik pisang dan atribut desai kemasan menarik 
pada segi kemasan. Atribut tertinggi menunjukkan prioritas yang perlu diperhatikan dan dilakukan perbaikan.

9. Rancangan Persyaratan Teknis

Korelasi teknis digunakan untuk mengidentifikasi dimana masing-masing respon teknis saling mendukung atau tidak didalam perencanaan perbaikan. Hubungan gambar 1 ini diperoleh melalui kuesioner dan wawancara kepada dua narasumber yaitu pihak UD. Syahriyah dan Dosen TIP.

10. Penentuan Prioritas Persyaratan Teknis

Penentuan Prioritas didasarkan pada bobot respon teknis yang diurutkan mulai dari nilai bobot respon teknis paling tinggi sampai paling rendah. Nilai tabel diatas didapatkan dengan mengalikan nilai hubungan dengan nilai NRW. Urutan prioritas tertinggi pada segi produk adalah lama penggorengan dan suhu penggorengan sedangkan dari segi kemasan atribut kelengkapan informasi label yang merupakan peringkat tertinggi.

\section{E. Penutup}

1. Kesimpulan

a. Terdapat tujuh belas atribut kebutuhan konsumen yang harus diperhatikan dalam pengembangan produk keripik pisang. Terdiri dari sebelas atribut kebutuhan konsumen berhubungan dengan produk dan terdiri dari enam atribut kebutuhan konsumen dari segi kemasan.

b. Terdapat dua puluh satu atribut persyaratan teknis dalam pengembangan produk. Enam belas atribut dari segi produk nilai tertinggi dari segi produk adalah lama penggorengan dan suhu penggorengan. Lima atribut dari segi kemasan nilai tertinggi segi kemasan yang menjadi prioritas utama untuk diperhatikan dalam pengembangan produk keripik pisang adalah kelengkapan informasi lebel.

c. Terdapat beberapa nilai IR yang perlu diperbaikan dalam pengembangan produk keripik pisang.

2. Saran

a. Perlu adanya pengembangan lebih terhadap pendiskripsian keinginan pelangan secara utuh.

b. Peneliti perlu melakukan optimasi dan perbaikan-perbaikan mutu dengan menyelesaikan Matrik (R2), Matrik (R3), Matrik (R4).

\section{F. Daftar Pustaka}

Machyudi, Y. 2009. Pengaruh biaya pengembangan produk terhadap volume penjualan pada CV. Panamas Ligar Perkasa Rajapolah Tasikmalaya. JurnalAkuntansi Fakultas Ekonomi Universitas Siliwangi. 4 (1): 586-593. 
Prihatini., Diah S. N., Endang, P .P. 1999. Mengenal Buah Unggul Indonesia. Jakarta: Penebar Swadaya.

WiJaya, T. 2011. Manajemen Kualitas Jasa: Desain Servqural, QFD, dan Kano Disertai Contoh Aplikasi dalam Kasus Penelitian. Jakarta: PT. Indeks. 
Tabel 1. Data Perhitungan

\section{LAMPIRAN}

\begin{tabular}{|c|c|c|c|c|c|c|c|c|c|c|}
\hline Atril & $\begin{array}{l}\text { It Kebutuhan } \\
\text { onsumen }\end{array}$ & TKK & $\mathbf{r}_{\mathrm{xy}}$ & $\sigma_{b^{2}}$ & TKP & $\begin{array}{c}\text { Nilai } \\
\text { Target }\end{array}$ & IR & $\mathbf{P P}$ & $\mathbf{R W}$ & NRW \\
\hline \multirow{12}{*}{ Produk } & $\begin{array}{l}\text { Bahan baku } \\
\text { berkualitas baik }\end{array}$ & 4,45 & .376 & 0,329 & 0,03 & 4,45 & 1,12 & 1,41 & 7,017 & 0,101 \\
\hline & $\begin{array}{l}\text { Memiliki rasa } \\
\text { manis dan gurih }\end{array}$ & 4,12 & .403 & 0,258 & 0,02 & 4,13 & 1,00 & 1,37 & 5,649 & 0,082 \\
\hline & $\begin{array}{l}\text { Menambah varian } \\
\text { rasa }\end{array}$ & 3,53 & .341 & 0,819 & 0,02 & 3,53 & 1,21 & 1,26 & 5,398 & 0,078 \\
\hline & $\begin{array}{l}\text { Tekstur keripik } \\
\text { renyah tidak alot }\end{array}$ & 4,69 & .306 & 0,227 & 0,02 & 4,69 & 1,15 & 1,33 & 7,115 & 0,103 \\
\hline & $\begin{array}{l}\text { Menggunakan } \\
\text { pemanis alami } \\
\text { (gula) }\end{array}$ & 4,60 & .302 & 0,309 & 0,02 & 4,60 & 1,16 & 1,37 & 7,319 & 0,106 \\
\hline & $\begin{array}{l}\text { Tidak ada bahan } \\
\text { pengawet }\end{array}$ & 4,40 & .291 & 0,426 & 0,02 & 4,40 & 1,09 & 1,43 & 6,829 & 0,099 \\
\hline & $\begin{array}{l}\text { Produk higienis } \\
\text { dan sehat untuk } \\
\text { dikonsumsi }\end{array}$ & 4,28 & .516 & 0,492 & 0,02 & 4,30 & 1,00 & 1,40 & 5,973 & 0,086 \\
\hline & Harga marah & 4,01 & .278 & 0,378 & 0,02 & 4,01 & 1,03 & 1,34 & 5,542 & 0,080 \\
\hline & $\begin{array}{l}\text { Inovasi bentuk } \\
\text { (tidak selalu oval) }\end{array}$ & 3,20 & .483 & 0,903 & 0,02 & 3,20 & 1,16 & 1,19 & 4,405 & 0,064 \\
\hline & $\begin{array}{l}\text { Warna keripik } \\
\text { kuning kecoklatan }\end{array}$ & 4,19 & .299 & 0,690 & 0,02 & 4,19 & 1,28 & 1,22 & 6,521 & 0,094 \\
\hline & $\begin{array}{l}\text { Tidak banyak } \\
\text { minyak } \\
\text { mengendap pada } \\
\text { keripik pisang }\end{array}$ & 4,68 & .486 & 0,264 & 0,01 & 4,68 & 1,17 & 1,34 & 7,382 & 0,107 \\
\hline & TOTAL & & & & & 46,18 & & 14,66 & 69,149 & 1,000 \\
\hline \multirow{7}{*}{ Kemasan } & $\begin{array}{l}\text { Mencantumkan } \\
\text { label halal, } \\
\text { komposisi, dan } \\
\text { tanggal kadaluarsa }\end{array}$ & 4,56 & .514 & 0,351 & 0,01 & 4,56 & 1,46 & 1,43 & 9,551 & 0,197 \\
\hline & $\begin{array}{l}\text { Mencantumkan } \\
\text { BPOM }\end{array}$ & 3,91 & .532 & 0,673 & 0,02 & 3,91 & 1,41 & 1,43 & 7,854 & 0,162 \\
\hline & $\begin{array}{lr}\text { Kemasan } & \text { simpel } \\
\text { (plastik bening } & \text { ben } \\
\text { dengan penutup } & \text { sealer } \\
\text { alumunium } & \\
\text { dengan penutup } \\
\text { katupan) }\end{array}$ & 3,95 & .599 & 0,596 & 0,03 & 3,96 & 1,00 & 1,32 & 5,199 & 0,107 \\
\hline & $\begin{array}{l}\text { Desain produk } \\
\text { menarik }\end{array}$ & 4,49 & .352 & 0,424 & 0,01 & 4,49 & 1,60 & 1,39 & 9,943 & 0,205 \\
\hline & $\begin{array}{l}\text { Mencantumkan } \\
\text { netto (isi) }\end{array}$ & 4,20 & .624 & 0,542 & 0,02 & 4,20 & 1,44 & 1,33 & 8,064 & 0,167 \\
\hline & $\begin{array}{l}\text { Mencantumkan } \\
\text { merk produk dan } \\
\text { nama perusahaan }\end{array}$ & 4,41 & .413 & 0,324 & 0,34 & 4,41 & 1,26 & 1,40 & 7,813 & 0,161 \\
\hline & TOTAL & & & & & 25,53 & & 8,30 & 48,425 & $\mathbf{1 , 0 0 0}$ \\
\hline
\end{tabular}

Tabel 2. Perbandingan Produk Kompetitor

\begin{tabular}{|c|c|c|c|}
\hline & Atribut Kebutuhan Konsumen & UD. Syahriyah & UD. Melati \\
\hline \multirow{8}{*}{ Produk } & Bahan baku berkualitas baik & 3,98 & 3,84 \\
\hline & Memiliki rasa manis dan gurih & 4,13 & 3,95 \\
\hline & Menambah varian rasa & 2,91 & 3,37 \\
\hline & Tekstur keripik renyah tidak alot & 4,09 & 3,94 \\
\hline & Menggunakan pemanis alami (gula) & 3,97 & 3,96 \\
\hline & Tidak ada bahan pengawet & 4,04 & 3,92 \\
\hline & Inovasi bentuk (tidak selalu oval) & 2,77 & 3,16 \\
\hline & Warna keripik kuning kecoklatan & 3,28 & 3,59 \\
\hline
\end{tabular}




\begin{tabular}{|c|c|c|c|}
\hline & Tidak banyak minyak pada keripik pisang & 3,99 & 3,95 \\
\hline & Total & 41,35 & 41,53 \\
\hline \multirow{6}{*}{ Kemasan } & $\begin{array}{l}\text { Mencantumkan Label halal, komposisi, dan } \\
\text { tanggal kadaluarsa }\end{array}$ & 3,12 & 4,11 \\
\hline & Mencantumkan BPOM & 2,78 & 3,54 \\
\hline & $\begin{array}{l}\text { Kemasan simple (plastik bening dengan penutup } \\
\text { sealer dan alumunium dengan penutup katupan) }\end{array}$ & 3,96 & 3,74 \\
\hline & Desain produk menarik & 2,81 & 3,90 \\
\hline & Mencantumkan netto (isi) & 2,92 & 3,74 \\
\hline & $\begin{array}{l}\text { Mencantumkan merk produk dan nama } \\
\text { perusahaan }\end{array}$ & 3,49 & 3,49 \\
\hline & Total & 19,08 & 22,52 \\
\hline
\end{tabular}

\section{Gambar 1. House Of Quality Segi Produk}

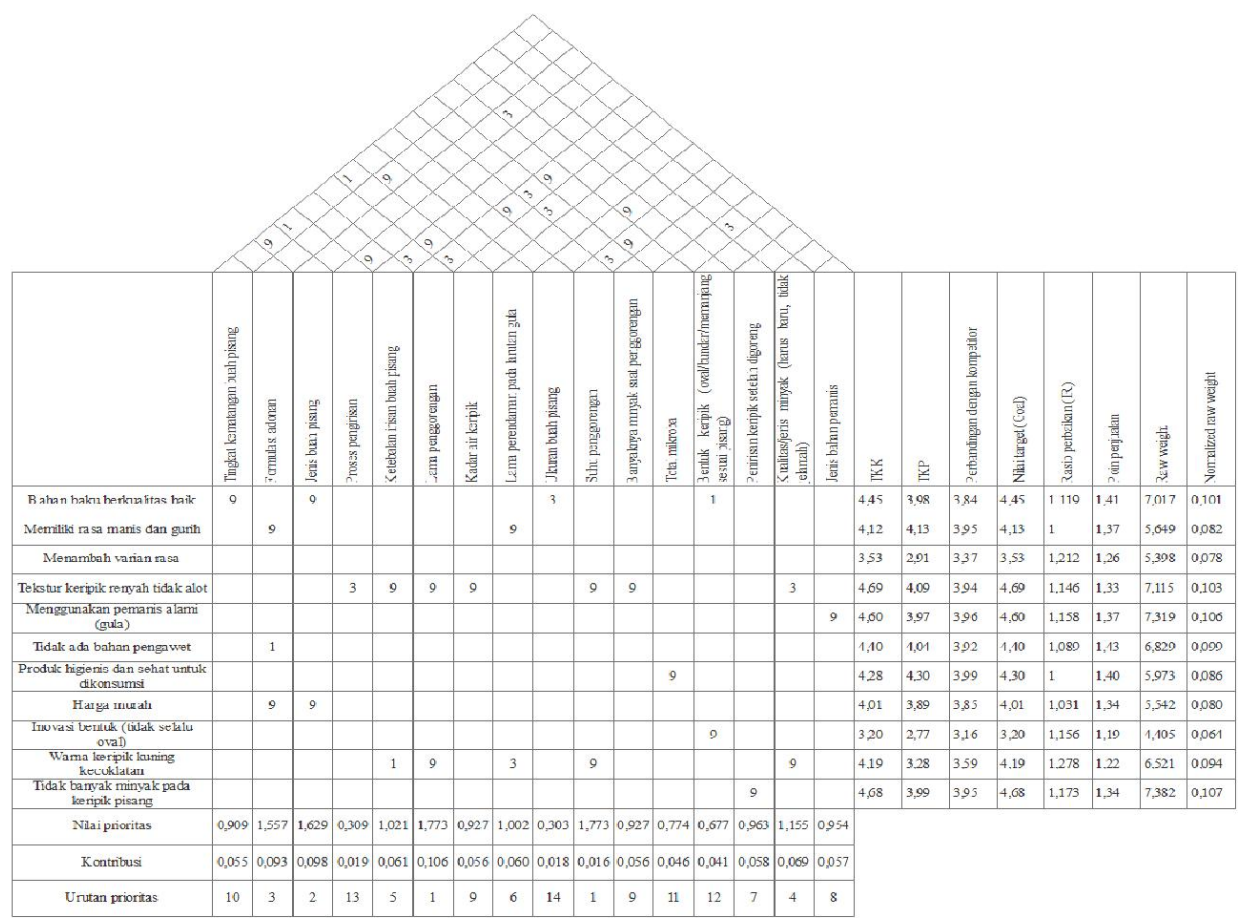

\section{Gambar 2. House Of Quality Segi Kemasan}

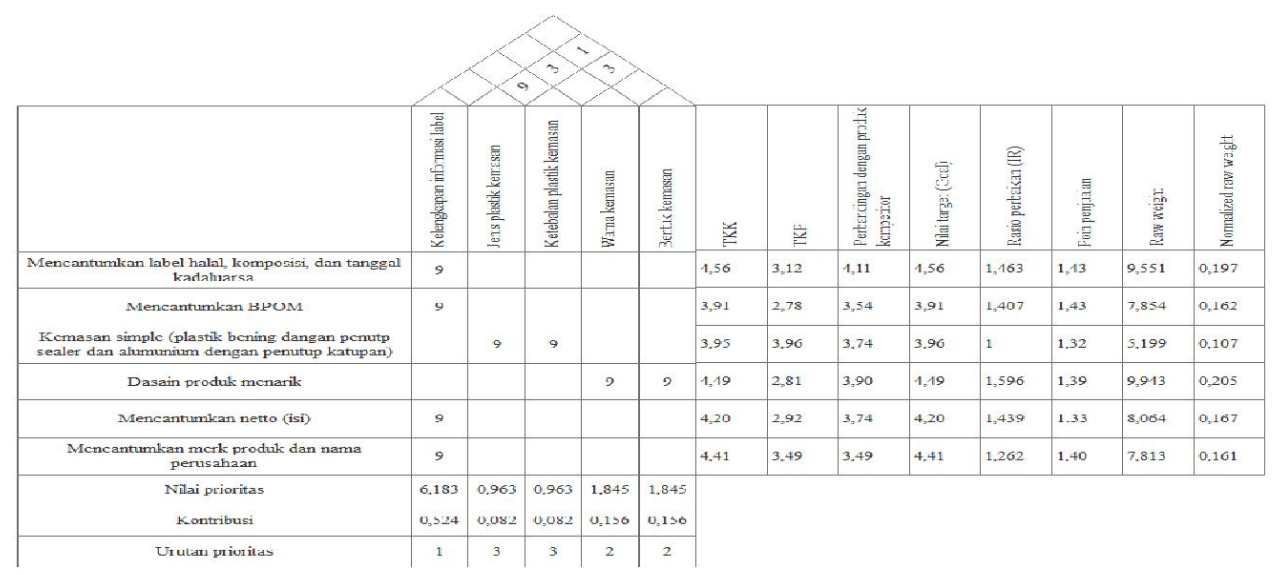


Tabel 3. Persyaratan Teknis

\begin{tabular}{|c|c|c|c|c|c|c|}
\hline No & Persyaratan Teknis & Atribut Kebutuhan Konsumen & $\begin{array}{c}\text { Nilai } \\
\text { Hubungan }\end{array}$ & NRW & Prioritas & Kontribusi \\
\hline 1 & Tingkat kematangan buah pisang & Bahan baku berkualitas baik & 9 & 0,101 & 0,909 & 0,055 \\
\hline \multirow{3}{*}{2} & \multirow{3}{*}{ Formulasi adonan } & Memiliki rasa manis dan gurih & 9 & 0,082 & \multirow{3}{*}{1,557} & \multirow{3}{*}{0,093} \\
\hline & & Tidak ada bahan pengawet & 1 & 0,099 & & \\
\hline & & Harga Murah & 9 & 0,080 & & \\
\hline \multirow{2}{*}{3} & \multirow{2}{*}{ Jenis buah pisang } & Bahan baku berkualitas baik & 9 & 0,101 & \multirow{2}{*}{1,629} & \multirow{2}{*}{0,098} \\
\hline & & Harga Murah & 9 & 0,080 & & \\
\hline 4 & Proses pengirisan & Tekstur keripik renyah tidak alot & 3 & 0,103 & 0,309 & 0,019 \\
\hline \multirow{2}{*}{5} & \multirow{2}{*}{ Ketebalan irisan buah pisang } & Tekstur keripik renyah tidak alot & 9 & 0,103 & \multirow{2}{*}{1,021} & \multirow{2}{*}{0,061} \\
\hline & & Warna keripik kuning kecoklatan & 1 & 0,094 & & \\
\hline \multirow{2}{*}{6} & \multirow{2}{*}{ Lama penggorengan } & Tekstur keripik renyah tidak alot & 9 & 0,103 & \multirow{2}{*}{1,773} & \multirow{2}{*}{0,106} \\
\hline & & Warna keripik kuning kecoklatan & 9 & 0,094 & & \\
\hline 7 & Kadar air keripik & Tekstur keripik renyah tidak alot & 9 & 0,103 & 0,927 & 0,056 \\
\hline \multirow{2}{*}{8} & \multirow{2}{*}{ Lama perendaman pada larutan gula } & Memiliki rasa manis dan gurih & 9 & 0,080 & & \multirow{2}{*}{0,060} \\
\hline & & Warna keripik kuning kecoklatan & 3 & 0,094 & & \\
\hline 9 & Ukuran buah pisang & Bahan baku berkualitas baik & 3 & 0,101 & 0,303 & 0,018 \\
\hline \multirow{2}{*}{10} & \multirow{2}{*}{ Suhu penggorengan } & Tekstur keripik renyah tidak alot & 9 & 0,103 & \multirow{2}{*}{1,773} & \multirow{2}{*}{0,106} \\
\hline & & Warna keripik kuning kecoklatan & 9 & 0,094 & & \\
\hline 11 & Banyaknya minyak saat penggorengan & Tekstur keripik renyah tidak alot & 9 & 0,103 & 0,927 & 0,056 \\
\hline 12 & Total mikroba & Produk higienis dan sehat untuk dikonsumsi & 9 & 0,086 & 0,774 & 0,046 \\
\hline \multirow{2}{*}{13} & \multirow{2}{*}{$\begin{array}{l}\text { Bentuk keripik (oval/bundar/memanjang } \\
\text { sesuai pisang) }\end{array}$} & Bahan baku berkualitas baik & 1 & 0,101 & \multirow{2}{*}{0,677} & \multirow{2}{*}{0,041} \\
\hline & & Inovasi bentuk (tidak selalu oval & 9 & 0,064 & & \\
\hline 14 & Penirisan keripik setelah digoreng & Tidak banyak minyak pada keripik & 9 & 0,107 & 0,963 & 0,058 \\
\hline \multirow{2}{*}{15} & \multirow{2}{*}{$\begin{array}{l}\text { Kualitas/jenis minyak (harus baru, tidak } \\
\text { jelantah) }\end{array}$} & Tekstur keripik renyah tidak alot & 3 & 0,103 & \multirow{2}{*}{1,155} & \multirow{2}{*}{0,069} \\
\hline & & Warna keripik kuning kecoklatan & 9 & 0,094 & & \\
\hline \multirow[t]{2}{*}{16} & Jenis bahan pemanis & Menggunakan pemanis alami (gula) & 9 & 0,106 & 0,954 & 0,057 \\
\hline & & Total & & & 16,653 & \\
\hline
\end{tabular}

Tabel 3. Persyaratan Teknis

\begin{tabular}{|c|c|c|c|c|c|c|}
\hline No & Persyaratan Teknis & Atribut Kebutuhan Konsumen & $\begin{array}{l}\text { Nilai } \\
\text { Hubungan }\end{array}$ & $\begin{array}{l}\text { Normalized } \\
\text { Raw Weight }\end{array}$ & Prioritas & Kontribusi \\
\hline \multirow{4}{*}{1} & \multirow{4}{*}{$\begin{array}{l}\text { Kelengkapan } \\
\text { informasi label }\end{array}$} & $\begin{array}{l}\text { Mencantumkan label halal, komposisi, dan tanggal } \\
\text { kadaluarsa }\end{array}$ & 9 & 0,197 & \multirow{4}{*}{6,183} & \multirow{4}{*}{0,524} \\
\hline & & Mencantumkan BPOM & 9 & 0,162 & & \\
\hline & & Mencantumkan netto (isi) & 9 & 0,167 & & \\
\hline & & Mencantumkan merk produk dan nama perusahaan & 9 & 0,161 & & \\
\hline 2 & Jenis plastik kemasan & $\begin{array}{l}\text { Kemasan simple (plastik bening dengan penutup } \\
\text { sealer dan alumunium dengan penutup katupan }\end{array}$ & 9 & 0,107 & 0,963 & 0,082 \\
\hline 3 & $\begin{array}{l}\text { Ketebalan plastik } \\
\text { kemasan }\end{array}$ & $\begin{array}{l}\text { Kemasan simple (plastik bening dengan penutup } \\
\text { sealer dan alumunium dengan penutup katupan }\end{array}$ & 9 & 0,107 & 0,963 & 0,082 \\
\hline 4 & Warna kemasan & Desain produk menarik & 9 & 0,205 & 1,845 & 0,156 \\
\hline \multirow[t]{2}{*}{5} & Bentuk kemasan & Desain produk menarik & 9 & 0,205 & 1,845 & 0,156 \\
\hline & \multicolumn{4}{|c|}{ Total } & 11,799 & \\
\hline
\end{tabular}

